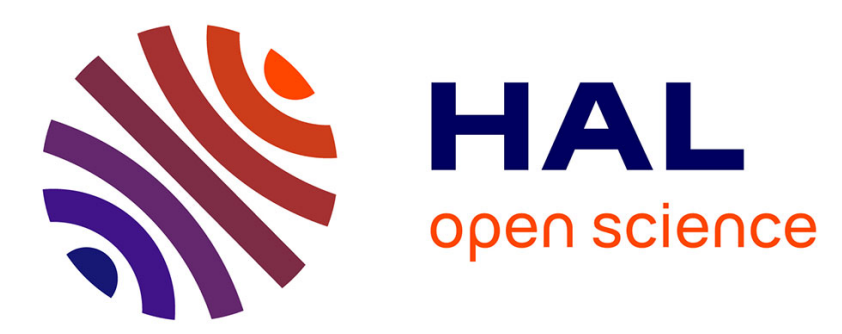

\title{
Stabilization of a Premixed Methane-Air Flame Using Nanosecond Repetitively Pulsed Discharges
}

\author{
Quang Lam L. Pham, Deanna A. Lacoste, C. Laux
}

\section{To cite this version:}

Quang Lam L. Pham, Deanna A. Lacoste, C. Laux. Stabilization of a Premixed Methane-Air Flame Using Nanosecond Repetitively Pulsed Discharges. IEEE Transactions on Plasma Science, 2011, 39 (11), pp.2264-2265. 10.1109/TPS.2011.2163806 . hal-00669374

\section{HAL Id: hal-00669374 https://hal.science/hal-00669374}

Submitted on 16 Feb 2012

HAL is a multi-disciplinary open access archive for the deposit and dissemination of scientific research documents, whether they are published or not. The documents may come from teaching and research institutions in France or abroad, or from public or private research centers.
L'archive ouverte pluridisciplinaire HAL, est destinée au dépôt et à la diffusion de documents scientifiques de niveau recherche, publiés ou non, émanant des établissements d'enseignement et de recherche français ou étrangers, des laboratoires publics ou privés. 


\section{Stabilization of a Premixed Methane-Air Flame Using Nanosecond Repetitively Pulsed Discharges}
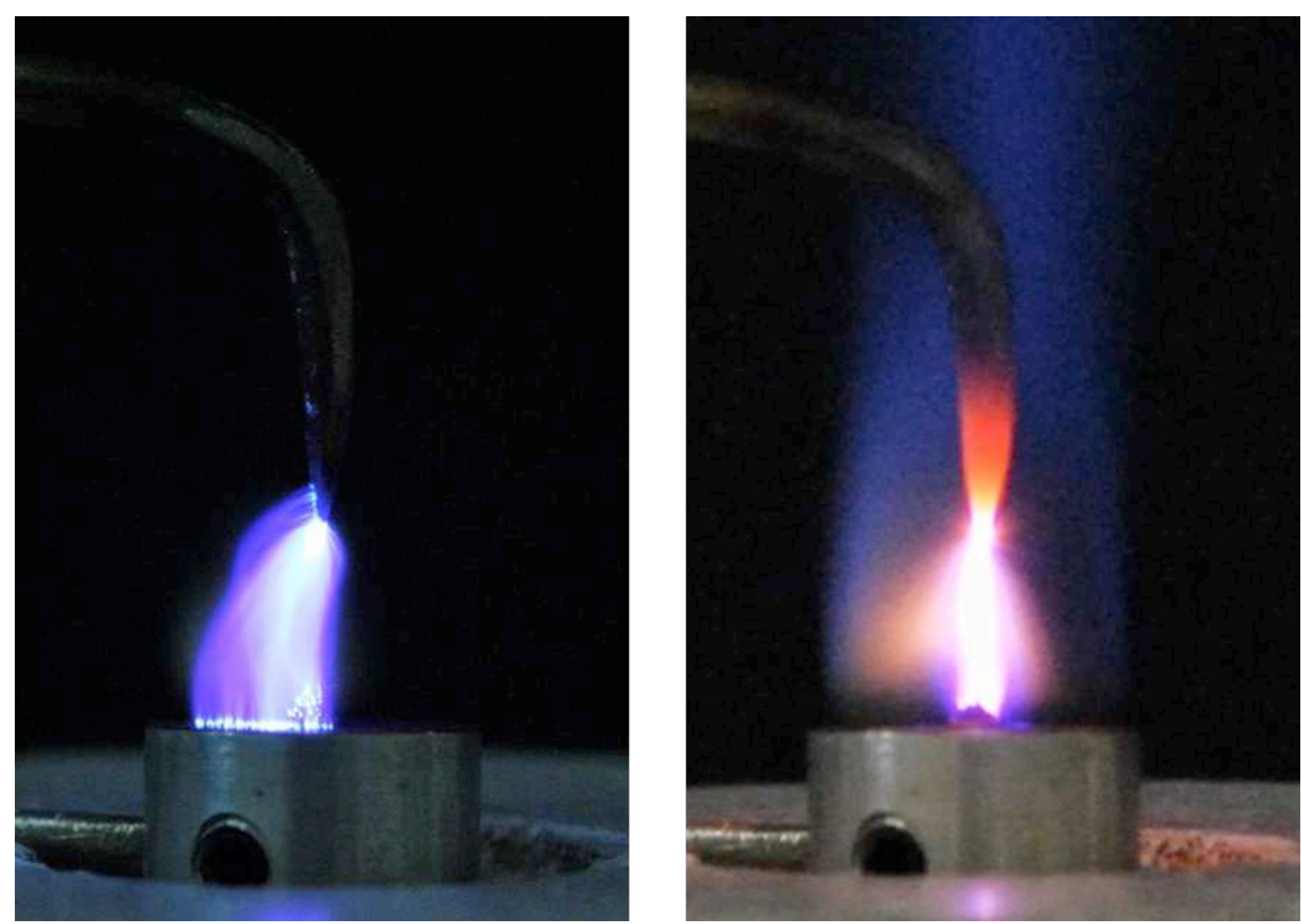

Fig. 1. Nanosecond Repetitively Pulsed plasma discharge (spark), without flame (left) and interacting with a lean flame (right). Characterization of the discharge: $\mathrm{f}=30 \mathrm{kHz}, \mathrm{V}=6.0 \mathrm{kV}$.

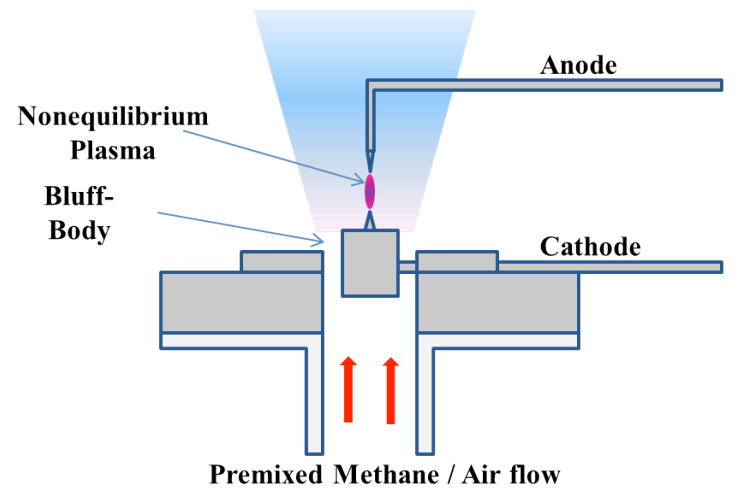

Fig. 2. Experimental setup with premixed burner diagram.

The cathode is grounded.

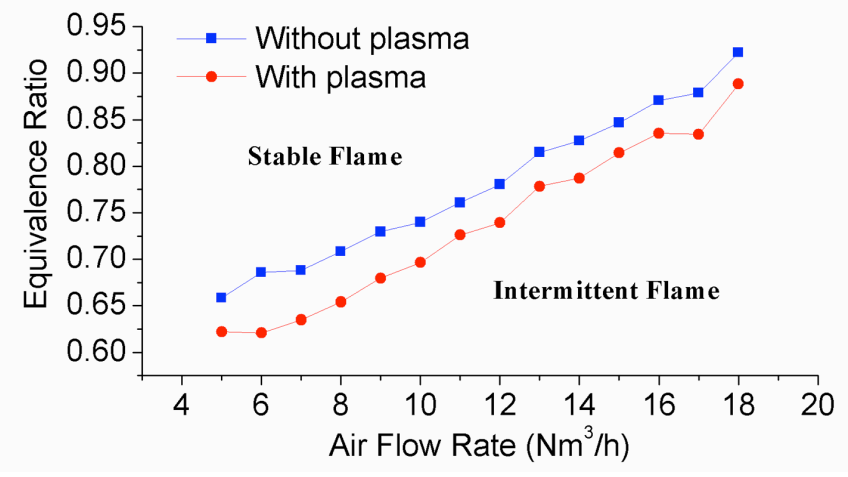

Fig. 3. Flammability limit with NRP plasma in spark regime 


\begin{abstract}
Nanosecond Repetitively Pulsed (NRP) discharges have been used for a broad range of applications, such as Plasma Assisted Combustion. In this study, we use a NRP plasma discharge produced by electric pulses of about $10 \mathrm{kV}$ during $10 \mathrm{~ns}$ at a frequency of $30 \mathrm{kHz}$ to stabilize a lean premixed methane/air flame at atmospheric pressure. We show here that the plasma created in the recirculation zone allows the stabilization of the lean flame and a reduction of the lean extinction limit by about 10-15\%, using only a small amount of energy (the plasma power represents less than $1 \%$ of the power of the flame).
\end{abstract}

Reducing pollutant emissions in combustion engines has become a major issue because of new environmental regulations. In a flame, the production of nitric oxides $\left(\mathrm{NO}_{\mathrm{x}}\right)$ is strongly related to the flame temperature.[1]-[2] Since this temperature is directly related to the fuel equivalence ratio $\Phi$, one way to reduce this temperature is to burn the fuel in lean conditions.[3] However, in these conditions, the flame becomes unstable and can eventually extinguish. Thus, stabilizing the lean flame is an issue that needs to be addressed. A similar study was carried out previously in our laboratory with a premixed propane/air flame. [3] For many applications involving natural gas turbines, it is also important to understand whether the observed positive stabilization can be also obtained with a lean premixed methane/air flame.

In this study, we are interested in the effects of the NRP plasma discharge on the combustion. The plasma discharge is located in the combustion zone between the two electrodes. A bluff-body (diameter $10 \mathrm{~mm}$ ) is used as a cathode and creates a recirculation zone. The space between the two electrodes is fixed at $5 \mathrm{~mm}$. The premixed burner is presented in Fig. 1 along with its configuration. The flow rates of air and methane are controlled by Bronkhorst Hi-Tec, El-flow electronic flow meters.

A non-equilibrium NRP plasma discharge is produced by a FID FPG 10-30MS generator, between two electrodes. The electric pulse has a duration of about $10 \mathrm{~ns}$, and an amplitude of several $\mathrm{kV}$. Depending on the pulse voltage, we can obtain three different regimes: corona, glow and spark. [4] The frequency is fixed at $\mathrm{f}=30 \mathrm{kHz}$, which results in less electric power consumed by the plasma discharge as compared to a continuous discharge. Voltage measurements are made with a Lecroy PPE $20 \mathrm{kV}$ highvoltage probe, and intensity measurements with a Pearson Electronics 6585 coil, with a Lecroy WavePro 7000 oscilloscope.

The higher the pulse voltage is, the more luminous and powerful the discharge will be. In this study, only the spark discharge can stabilize a lean flame. There is a significant increase in the energy provided to the discharge at the transition between the two main regimes (glow and spark). However, even at the highest voltage allowed by the experimental setup, the energy provided to a single pulse is only $1.6 \mathrm{~mJ}$, which corresponds to an average power of only $48 \mathrm{~W}$ at a $30 \mathrm{kHz}$ repetition frequency. This represents less than $1 \%$ of the power of the flame.

By decreasing the fuel flow rate at a constant air flow rate, four flame regimes are observed before the flame blows out:

- Main regime: stable, strong V-shaped flame

- Intermittent flame

- Totally unstable flame

- Pilot flame (confined to the recirculation zone)

Finally, Fig. 3 shows the extended domain of flame stability when using the spark discharge. An $\mathbf{1 1 \%}$ decrease in the lean extinction limit is obtained.

In conclusion, images of an experimental plasma assisted combustion study have been presented. It has been shown that it was possible to stabilize the combustion of a lean premixed methane/air flame using NRP plasma discharges, with less than $1 \%$ of the power of the flame. These results are comparable to those obtained with a propane/air flame - study carried out by Guillaume Pilla and are thus promising for industrial applications.

\section{REFERENCES}

[1] Lefebvre, A. H. (1999). Gas Turbine Combustion. Taylor and Francis, Philadelphia.

[2] Steele, R. C., P. C. Malte, D. G. Nicol, J. C. Kramlich (1999). "NO$O_{x}$ and $\mathrm{N}_{2} \mathrm{O}$ in Lean-Premixed Jet-Stirred Flames," Combustion Laboratories, Department of Mechanical Engineering, University of Washington.

[3] Pilla, G., Lacoste, D.A., Veynante, D., and Laux, C.O., "Stabilization of a Propane-Air Swirled Flame using a Nanosecond Repetitively Pulsed Plasma," IEEE Transactions on Plasma Science, Vol. 36, No. 4, pp. 940-941, 2008.

[4] Pai, D.Z., Lacoste, D.A., and Laux, C.O., 'Transitions between corona, glow, and spark regimes of nanosecond repetitively pulsed discharges in air at atmospheric pressure," J. Appl. Phys., 107, 093303, 2010. 